\title{
PENGARUH PROBLEM BASED LEARNING BERBANTUAN MEDIA AUDIO VISUAL TERHADAP KEMAMPUAN BERPIKIR KRITIS DAN HASIL BELAJAR IPA DI SEKOLAH DASAR
}

\author{
Dyah Aini Purbarani ${ }^{1}$, Nyoman Dantes ${ }^{2}$, Putu Budi Adnyana ${ }^{3}$ \\ Program Studi Pendidikan Dasar, Program Pascasarjana \\ Universitas Pendidikan Ganesha \\ Singaraja, Indonesia \\ e-mail: maha.r4ny@gmail.com, \\ \{ nyoman.dantes, budi.adnyana\}@pasca.undiksha.ac.id
}

\begin{abstract}
Abstrak
Penelitian ini memiliki tujuan utama untuk mengetahui pengaruh problem based learning berbantuan media audio visual terhadap kemampuan berpikir kritis dan hasil belajar IPA siswa. Populasi penelitian ini adalah seluruh siswa kelas III gugus $X$ Buleleng yang berjumlah 102 siswa dan sampel berjumlah 58 siswa. Penetapan sampel dilakukan dengan teknik random sampling. Penelitian ini merupakan quasi eksperimen dengan rancangan Nonequivalent Posttest Only Control Group Design. Teknik pengumpulan data kemampuan berpikir kritis menggunakan tes essay sedang data hasil belajar IPA menggunakan tes pilihan ganda. Data dianalisis menggunakan uji manova. Berdasarkan penelitian yang telah dilakukan dapat disimpulkan bahwa: 1) terdapat pengaruh pendekatan saintifik berbasis problem based learning berbantuan media audio visual terhadap kemampuan berpikir kritis pada siswa kelas III di sekolah dasar; 2) terdapat pengaruh pendekatan saintifik berbasis problem based learning berbantuan media audio visual terhadap hasil belajar IPA pada siswa kelas III di sekolah dasar; dan 3) terdapat pengaruh pendekatan saintifik berbasis problem based learning berbantuan media audio visual terhadap kemampuan berpikir kritis dan hasil belajar IPA secara simultan pada siswa kelas III di sekolah dasar.
\end{abstract}

Kata kunci: problem based learning, media audio visual, kemampuan berpikir kritis, hasil belajar IPA

\begin{abstract}
This study has the main objective to determine the effect of problem based learning by using audio visual media on student's critical thinking skills and learning outcomes of Natural Sciences Lesson. The population of this study were all students of third class on $X$ group of Buleleng which consist of 102 students and the sample of this research are 58 students of them. Determination of the sample is done by random sampling technique. This research is a quasi-experimental design with Nonequivalent Posttest Only Control Group Design. The data collection technique of critical thinking ability uses essay tests while the science learning outcomes data uses multiple choice tests. Data were analyzed using manova test . Based on the research that has been done, it can be concluded that: 1) there was the effect of a problem based learning-based scientific approach assisted by audio visual media on critical thinking skills in third grade students in elementary school; 2) there was also an effect of a problem based learning-based scientific approach assisted by audio visual media on science learning outcomes in third grade students in elementary school; and 3) therefore there is simultaneously effect of scientific approach using problem based learning assisted by audio visual media on critical thinking skills and learning outcomes of the third class students on Natural sciences lesson in elementary school.
\end{abstract}

Keywords : problem based learning, audio visual media, critical thinking skills, natural sciences learning outcomes. 


\section{PENDAHULUAN}

Pendidikan merupakan suatu usaha yang dilandasi kesadaran dan terencana untuk menciptakan proses pembelajaran dan suasana belajar. Tujuan dari pendidikan nasional adalah mengembangkan kemampuan dan membentuk watak serta peradaban bangsa yang bermartabat dalam rangka mencerdaskan kehidupan bangsa, agar menjadi manusia yang beriman dan bertakwa kepada Tuhan Yang Maha Esa, berakhlak mulia, sehat, berilmu, cakap, kreatif, mandiri, dan menjadi warga negara yang demokratis serta bertanggung jawab (Undang-undang Republik Indonesia No. 20 Tahun 2003). Pendidikan merupakan investasi jangka panjang yang memerlukan usaha dan dana yang cukup besar, hal ini diakui oleh semua orang atau suatu bangsa demi kelangsungan masa depannya.

Menurut Ki Hajar Dewantara tujuan pendidikan adalah penguasaan diri, sebab pendidikan harus memanusiakan manusia (humanisasi) karena manusia memiliki daya jiwa yaitu cipta, karsa dan karya. Untuk memfasilitasi kebutuhan tersebut, proses pendidikan perlu mendapatkan perhatian, penanganan dan prioritas dari pemerintah, masyarakat dan para penyelenggara pendidikan. Penyelenggaraan salah satunya adalah pendidikan formal yaitu pendidikan di sekolah. Pendidikan di sekolah diberikan dengan kepercayaan dan keyakinan bahwa peserta didik dapat dididik dan belajar dengan menyenangkan, menumbuhkan semangat dan membuat peserta didik beranggapan bahwa belajar itu merupakan suatu hasil pengalaman dalam kehidupannya sehari-hari.

Pendidikan SD memiliki peran yang besar sebagai pondasi atau dasar ilmu pengetahuan dan dasar penciptaan karakter yang digunakan sebagai modal untuk melanjutkan pendidikan ke jenjang selanjutnya. Upaya didalam meningkatkan pendidikan yang optimal tentu tidak terlepas dari peran pendidik dan orang tua yang berperan penting didalam mendidik peserta didik. Peran pendidik dan orang tua yang terus dan tiada hentinya membina peserta didik untuk maju didalam mengembangkan bakatnya, akan menjadikan peserta didik memiliki sikap rasa ingin tahu yang tinggi terhadap ilmu pengetahuan. Sikap rasa ingin tahu diperlukan peserta didik untuk mendorong agar peserta didik tertarik didalam mempelajari ilmu yang baru ataupun menggali informasi yang dalam kegiatan belajar mengajar.

Pembelajaran

merupakan implementasi dalam pendidikan untuk memenuhi tujuan pendidikan nasional. Guru mempunyai peran penting dalam menciptakan lingkungan belajar yang nyaman bagi siswa. Sedang kurikulum sebagai instrument sample pendidikan yang diberikan kepada peserta didik. Lingkungan belajar yang nyaman akan membuat belajar menjadi nyaman pula. Aunurrahman (2012:35), belajar merupakan perubahan tingkah laku pada diri individu berkat adanya interaksi antara individu dengan individu, dan individu dengan lingkungannya sehingga mereka mampu berinteraksi dengan lingkungannya.

Zaman modern seperti sekarang ini, baik pendidik maupun peserta didik dihadapkan pada tantangan era globalisasi. Era ini ditandai dengan keterampilan-keterampilan masyarakat yang semakin berkembang. Selain keterampilan dasar (membaca, menulis dan berhitung) masyarakat juga dituntut memiliki kemampuan belajar sepanjang hayat, mengelola informasi, mengelola sumber daya, mengelola hubungan sosial, mengelola diri , memecahkan masalah, mengambil keputusan, berpikir kreatif, dan lain sebagainya. Untuk itu, hal tersebut harus disiapkan, salah satunya dengan pendidikan. Salah satu mata pelajaran yang berkontribusi besar dalam membentuk sikap-sikap diatas adalah IImu Pengetahuan Alam (sains). Tujuan pengajaran sains ini sekarang mengalami perubahan dari penekanan pada kemampuan warganegara agar sadar sains (scientific literacy) kepada sadar sains dan teknologi (scientific and technological literacy).

Pembelajaran kurikulum 2013 berorientasi kepada usaha-usaha penyiapan lahirnya generasi emas 
Indonesia 2045 yang didambakan, yaitu generasi yang memiliki kompetensi yaitu sikap, pengetahuan dan keterampilan yang harus dimiliki, dihayati, dan dikuasai oleh peserta didik setelah mempelajari suatu muatan pembelajaran, menamatkan suatu program, atau menyelesaikan satuan pendidikan tertentu. Kurikulum 2013 ini lebih menyorot pendidikan karakter bangsa yang dijunjung tinggi. Pelaksanaan pembelajaran kurikulum 2013 ini menggunakan pendekatan scientific. Hidayati (2016) menyatakan Scientific is an approach to learning students actively integrating students in the process of thinking and the use of methods that are scientifically proven by conducting experiments to test the hypothesis, with the advantages of encouraging and inspiring students to think critically, to inspire learners are able to think hypothetically see the different, similarities and link to one another on the substance of learning materials. Dengan demikian, pendekatan scientific dapat mendorong siswa untuk berpikir kritis.

Pelaksanaan kurikulum 2013 pada SD/MI dilakukan melalui pembelajaran dengan pendekatan tematik-terpadu dari kelas I sampai dengan VI. Hal ini untuk lahirnya generasi penerus bangsa yang produktif, kreatif, inovatif, dan berkarakter. Dengan kreativitas, anak-anak bangsa mampu berinovasi secara produktif untuk menjawab tantangan masa depan yang semakin rumit dan kompleks. Keberhasilan Kurikulum 2013 dalam menghasilkan peserta didik yang produktif, kreatif, dan inovatif. Tolak ukur dari suksesnya penerapan Kurikulum 2013 berkaitan dengan beberapa faktor kunci yaitu : (1). Kepemimpinan Kepala Sekolah, (2). Kreativitas Guru, (3). Aktivitas Peserta Didik, (4). Sosialisasi, (5). Fasilitas dan Sumber Belajar, (6). Lingkungan Akademik yang Kondusif, dan (7). Partisipasi Warga Sekolah. (Mulyasa, 2013: 36)

Kurikulum 2013 ini digunakan untuk menghadapi tantangan pembelajaran era globalisasi abad 21 dimana era ini ditandai dengan perkembangan ilmu pengetahuan. Terutama pada bidang teknologi dan informasi, beragam informasi dapat diakses oleh siapapun dimanapun. Komisi internasional untuk pendidikan abad ke-21 yang dibentuk oleh UNESCO melaporkan di era global ini pendidikan dilaksanakan dengan bersandar pada empat pilar pendidikan yaitu learning to now, learning to do, learning to be dan learning to live together sebagaimana yang diungkapkan Delors (dalam Dantes, 2014: 18).

Wijaya (2016) mengemukakan Keterampilan abad 21 menyangkut: (1) life and career skills, (2) learning and innovation skills, dan (3) Information media and technology skills. Ketiga keterampilan tersebut dirangkum dalam sebuah skema yang disebut dengan pelangi keterampilan pengetahuan abad 21. Pada Learning and innovation skills (keterampilan belajar dan berinovasi) meliputi (a) berpikir kritis dan mengatasi masalah/Critical Thinking and Problem Solving, (b) komunikasi dan kolaborasi/Communication and Collaboration, (c) kreativitas dan inovasi/Creativity and Innovation.

Menurut Masyhud (2014:3) guru professional hendaknya memiliki 4 kompetensi, yaitu: 1) kompetensi pedagogik 2) kompetensi kepribadian/personal 3) kompetensi profesional, dan 4) kompetensi sosial. Keempat kompetensi tersebut hendaknya saling seimbang antara satu sama lainnya. Mulai dari kompetensi pedagogik yang menyangkut penguasaan terhadap hal-hal yang akan dibelajarkan, kepribadian seorang pendidik yang mampu memberikan contoh yang baik pada siswasiswanya, profesionalitas sebagai 2 pendidik yang bertanggungjawab atas tugas yang telah diembannya dan juga seorang pendidik yang mampu bersosialisasi dengan lingkungan sekitarnya. Guru mengajarkan bagaimana siswa harus belajar, sedangkan siswa belajar bagaimana seharusnya belajar melalui berbagai pengalaman belajar sehingga terjadi perubahan dalam dirinya dari aspek kognitif, psikomotorik, dan afektif. Guru yang berkompeten akan lebih mampu menciptakan lingkungan belajar yang efektif dengan memanfaatkan segala sesuatu yang ada disekitarnya sebagai sarana pembelajaran. Selain itu guru 
tersebut juga lebih mampu mengelola proses belajar mengajar, sehingga hasil belajar siswa berada pada tingkat yang optimal. Guru sebaiknya harus kreatif dalam merancang berbagai inovasi pembelajaran yang dapat mengembangkan keterampilan belajar dan berinovasi siswa. Kemampuan berpikir kritis dan pemecahan masalah merupakan hal yang berkaitan, karena pembelajaran berbasis masalah sangat memprioritaskan dan menyajikan masalah-masalah nyata pada kehidupan siswa sehari-hari yang membiasakan siswa untuk berpikir kritis dalam menyelesaikan masalah. Dengan melakukan komunikasi dan kolaborasi siswa dapat belajar untuk bekerjasama dan bertanggung jawab dalam segala keputusan dan tindakan yang dilakukan dalam penyelesaian masalah tersebut. Dalam menyelesaikan masalah siswa akan dipaksa untuk berpikir kritis dan kreatif, terlebih jika siswa mampu untuk berinovasi dalam menyelesaikan masalah tersebut.

Era Revolusi Industri 4.0 terjadi Era Disruptif teknologi, pemerintah melalui jalur pendidikan selalu mengembangkan kurikulum baik pada jenjang pendidikan dasar (SD dan SMP) dan pendidikan menengah (SMA/SMK). Pemberlakuan Kurikulum 2013 memiliki ciri utama "saintific approach" dan pengalaman belajar 5M. Menurut Hidayati (2016) Steps of Scientific Approach is:

1. Observing with learning activities Seeing, hearing, reading, listening (sign and instrumen)

2. Questioning with learning activitiesAsking questions of a factual question to the question hypothetical. Beginning with the guidance of teachers to independently

3. Assocciating with learning activities Determining the necessary data from questions Specifies the data source either from books, the Internet and books other than textbooks.

4. Reasoning with learning activities Analyzing the data into categories, define data relationships, concluded from analysis of data from the data structure that is simple to the complex
5. Communicating with learning activities Delivering results conceptualization in writing, orally or pictures and diagrams.

Menurut Wijayanti Pemanfaatan teknologi informasi dan komunikasi dalam pembelajaran menjadi inovasi pembelajaran berdampak positif. Tidak hanya dari segi minat belajar namun juga dari hasil belajar. Penggunaan berbagai aplikasi digital, CD pembelajaran interaktif, ebook, website, dan gaya belajar digital lainnya merupakan alternatif paperless. Guru tidak perlu mencetak berlembarlembar soal tes bagi siswanya. Siswa dapat menempuh evaluasi dengan berbagai aplikasi online seperti edmodoo dan kahoot.

Pembelajaran IPA dikatakan berhasil apabila semua tujuan pembelajaran yang telah ditentukan dapat tercapai, yang terungkap dalam hasil belajar IPA. IPA merupakan mata pelajaran yang mempelajari peristiwaperistiwa yang terjadi di alam. Pelajaran IPA di SD memuat materi tentang pengetahuan pengetahuan alam yang dekat dengan kehidupan siswa SD. Siswa diharapkan dapat mengenal dan mengetahui pengetahuan-pengetahuan alam tersebut dalam kehidupan sehariharinya. Permendikbud No. 21 Tahun 2016 menyatakan bahwa siswa harus menunjukkan keterampilan berpikir, dan bertindak: kreatif, produktif, kritis, mandiri, kolaboratif dan komunikatif dalam bahasa yang jelas, sistematis, logis, dan kritis dalam karya yang estetis, dalam gerakan yang mencerminkan anak sehat, dan tindakan yang mencerminkan perilaku anak sesuai dengan tahap perkembangannya.

Menurut Agustiana (2017:273) esensi IPA sebagai alat dalam penemuan pengetahuan dengan jalan pengamatan, eksperimen dan pemecahan masalah. Pemecahan masalah sehari-hari pada pembelajaran IPA, peserta didik Indonesia kurang maksimal, didukung dengan hasil penelitian sains pada tingkat Internasional yang diselengarakan oleh didukung dengan hasil penelitian sains Programme for International Student Assessment (PISA) tahun 2012 memperlihatkan bahwa literasi sains anak-anak Indonesia 
menempati peringkat ke-64 dari 65 negara yang berpartisipasi. Dengan demikian, hasil belajar siswa pada pembelajaran IPA sesuai dengan PISA dikategorikan rendah. Sesuai dengan keterampilan abad 21 IPA membutuhkan media dalam pengajarannya, karena Pelajaran IPA di SD tidak dapat terpisahkan oleh media pembelajaran. Sehingga guru haruslah paham pemahaman Information media and technology skills. Karena banyak materi pembelajaran IPA yang sulit dijelaskan dengan buku saja dan sulit dijangkau maka diperlukan media yang dapat menggambarkan keadaan nyatanya maka dipilih media audio visual. Penggunaan audio visual dalam pelajaran IPA di SD sangatlah bermanfaat, karena media audio visual memiliki fungsi-fungsi tertentu dalam proses belajar, diantaranya yaitu membangkitkan motivasi belajar siswa, dan rangsangan kegiatan belajar IPA, membantu kelancaran, efektivitas dan efesiensi pencapaian tujuan pembelajaran, serta membantu siswa berpikir kritis. Diharapkan dengan media audio visual dapat meningkatkan kualitas proses belajar siswa dalam pembelajaran yang pada gilirannya akan pula meningkatkan hasil belajarnya .

Hasil studi dokumentasi nilai ulangan IPA semester I tahun ajaran 2018/2019 di gugus X Kecamatan Buleleng pada siswa kelas III ditemukan hasil belajar siswa masih rendah. Sebagian siswa belum mencapai standar KKM kelas III yang telah ditentukan yaitu 75. Sejumlah siswa 43 atau $42,16 \%$ tuntas sedangkan 59 siswa atau $57,84 \%$ tidak tuntas.

Berdasarkan observasi tersebut diketahui bahwa rendahnya hasil belajar IPA semester I disebabkan oleh beberapa faktor. Adapun faktor yang menyebabkan hal tersebut diantaranya adalah : 1) metode yang digunakan guru selama pembelajaran berlangsung adalah ceramah dan penugasan. Selain itu guru hanya menggunakan buku teks saja dan media gambar. Media gambar memiliki kelemahan yaitu hanya medium visual, ukuran gambar seringkali kurang tepat untuk pengajaran dalam kelompok besar, dan memerlukan ketersediaan sumber keterampilan dan kejelian guru untuk dapat memanfaatkannya. Sehingga hal ini menyebabkan beberapa siswa kurang jelas terhadap penjelasan guru. Hal tersebut menyebabkan pembelajaran menjadi monoton dan kurang bervariasi.

2) berdasar wawancara dengan guru kelas kemampuan siswa untuk berpikir kritis masih tergolong rendah, kemampuan siswa dalam memecahkan masalah selama proses pembelajaran masih kurang dan rasa ingin tahu masih rendah. Mereka kurang memperhatikan penjelasan guru, bergurau dengan temannya, membuat gaduh dalam kelas, asyik main sendiri dan kurang konsentrasi terhadap pelajaran. Selain itu siswa kebanyakan langsung mengambil informasi begitu saja tanpa mempertimbangkan terlebih dahulu apakah data yang mereka ambil benarbenar kredibel.

Berdasarkan uraian di atas dapat dikatakan bahwa model problem based learning berbantuan media audio visual dapat mempengaruhi kemampuan berpikir kritis dan hasil belajar IPA siswa. Penggunaan media audio visual dan model pembelajaran Problem Based Learning untuk pembelajaran pada tema IPA sangat mendukung proses penyampaian informasi dari guru ke siswa karena media audio visual memiliki kemampuan untuk memaparkan sesuatu yang rumit, kompleks dan sulit yang tidak dapat dijelaskan bila hanya menggunakan media gambar atau kata-kata saja. Selain itu dengan menampilkan permasalahan dalam bentuk media audio visual dapat menumbuhkan kemampuan berpikir kritis siswa dalam menyelesaikan permasalahan dalam pembelajaran, sehingga dapat menunjang proses belajar yang menarik, menyenangkan dan bermakna bagi siswa. Peserta didik yang belajar memecahkan masalah akan menerapkan pengetahuan yang dimiliki atau berusaha mengetahui pengetahuan yang diperlukan; peserta didik yang mengintegrasikan pengetahuan dan keterampilan secara simultan dan mengaplikasikannya dalam konteks yang relevan; dapat meningkatkan kemampuan berfikir kritis, serta dapat mengembangkan 
hubungan interpersonal dalam bekerja kelompok.

Pada penelitian ini, dipilih pokok bahasan tema energi dan perubahannya. Pada pokok bahasan ini siswa harus dapat mengidentifikasi perubahan energi di lingkungan sekitar siswa namun banyak hal-hal yang bersifat abstrak. Sehingga sulit jika disampaikan secara verbal. Peneliti memanfaatkan media video untuk menampilkan bagaimana peristiwa tersebut berlangsung. Sehingga siswa dapat menerima gambaran nyata dari peristiwa tersebut.

Berdasarkan penelitian yang dilakukan Zejnilagić (2015) menyatakan Specific applications of cognitive and constructivist theories in problem-based learning (PBL) include connecting prior knowledge and skills with new information.

Results showed (1) significant improvement of students' achievements in $E G$, (2) these students are not used to this teaching method so they encountered certain difficulties, (3) overall interest and engagement in chemistry lessons has increased. Aplikasi spesifik teori kognitif dan konstruktivis dalam pembelajaran berbasis masalah (PBL) dapat menghubungkan pengetahuan dan keterampilan sebelumnya dengan informasi baru.

Garbier (2018) menyatakan The present results are One of the interests of computer-assisted reading is that it does not require the full-time presence of a teacher or an adult to accompany the child during reading. Overall, the present and previous research showed that RWL is economical since it can be used in the classroom with several children using the system in parallel. In addition, some results are encouraging regarding its potential benefits for beginning or struggling readers in particular. RWL ekonomis karena dapat digunakan di kelas dengan beberapa anak menggunakan sistem secara paralel. Selain itu, beberapa hasil sangat menggembirakan mengenai potensi manfaatnya bagi pembaca pemula atau yang kesulitan.

Pebriana (2017) menyatakan There is an increase in critical thinking skills in students whose learning uses a problem- based learning model is higher than students whose learning uses conventional learning. It can be concluded that the improvement of critical thinking ability in students whose learning using problem-based learning model is higher than students whose learning using conventional learning. This is because Problem-Based Learning is a strategy that begins by confronting students on real-life issues (authentic) or simulated problems, so students are required to think critically and place students as problem solver so that students become skilled in critical thinking. peningkatan kemampuan berpikir kritis pada siswa yang pembelajarannya menggunakan model problem-based learning lebih tinggi daripada siswa yang pembelajarannya menggunakan pembelajaran konvensional.

Asri (2019) menyatakan In this research by Audio-Visual Media Toward Positive Character and Learning Outcome, it could be seen that the average calculation score of the student's positive character pretest of the MI Kalibening Salatiga Islamic Elementary School's experimental class' students was 8 and the posttest mean score was 11. While the average control class' pretest was 8 and the posttest was 9. N-gain in the experimental class was 0.65 and $\mathrm{N}$-gain in the control class was 0.1 . So it could be concluded that there were increase in both experimental class and the control class but the experimental class has increased significantly compared to the control class and, to describe positive characters. Karakter Positif dan Hasil Belajar kelas eksperimen telah meningkat secara signifikan dibandingkan dengan kelas kontrol

Berdasarkan uraian di atas, maka dapat disimpulkan bahwa penelitian mereka berhasil. Sehingga dalam hal ini peneliti akan mengadakan penelitian yang berjudul "Pengaruh Pendekatan Pembelajaran Saintifik Berbasis Problem Based Learning Berbantuan Media Audio Visual Terhadap Kemampuan Berpikir Kritis dan Hasil Belajar IPA Siswa Kelas III Tema Energi dan Perubahannya Di Sekolah Dasar". 
Tujuan penelitian ini adalah: (1) Untuk mengetahui dan mendeskripsikan pengaruh pendekatan saintifik berbasis problem based learning berbantuan media audio visual terhadap kemampuan berpikir kritis pada siswa kelas III di sekolah dasar; (2) Untuk mengetahui dan mendeskripsikan pengaruh pendekatan saintifik berbasis problem based learning berbantuan media audio visual terhadap hasil belajar IPA pada siswa kelas III di sekolah dasar; (3) Untuk mengetahui dan mendeskripsikan pengaruh pendekatan saintifik berbasis problem based learning berbantuan media audio visual terhadap kemampuan berpikir kritis dan hasil belajar IPA secara simultan pada siswa kelas III di sekolah dasar

\section{METODE}

Penelitian ini merupakan penelitian eksperimen semu (quasi eksperimen) terhadap siswa dalam suatu kelas. Rancangan eksperimen yang digunakan adalah rancangan Nonequivalent Posttest Only Control Group Design. Dalam rancangan ini sampel yang diambil dari populasi diambil 2 kelas, dua kelas ini dipilih secara acak. Kelas pertama merupakan kelas eksperimen dan kelas kedua adalah kelas kontrol. Untuk kelas eksperimen dikenakan Pendekatan Pembelajaran Saintifik Berbasis Problem Based Learning berbantuan Media Audio Visual dan kelompok kontrol diberikan implementasi Pendekatan Pembelajaran Saintifik Berbasis Konvensional dalam jangka waktu tertentu, kemudian kedua kelompok dikenakan pengukuran yang sama. Perbedaan hasil pengukuran yang timbul di anggap sumber dari variabel pengukuran.

Tabel 1. Rancangan eksperimen

\begin{tabular}{|c|c|c|c|}
\hline \multicolumn{2}{|c|}{ A1 } & \multicolumn{2}{|c|}{ A2 } \\
\hline Y1 & Y2 & Y1 & $\mathrm{Y} 2$ \\
\hline $\begin{array}{l}\text { Keterang } \\
\text { A1 } \\
\text { A2 } \\
\text { Y1 } \\
\text { Y2 }\end{array}$ & $\begin{array}{l}\text { eksper } \\
\text { kontrol } \\
\text { npuan } \\
\text { elajar }\end{array}$ & Kritis & \\
\hline
\end{tabular}
semester 2 tahun ajaran 2018/2019. Populasi target dalam penelitian ini adalah seluruh siswa kelas III gugus X Buleleng yang berjumlah 102 siswa yang terdiri dari 4 rombel yaitu SDN 1 Kaliuntu, SDN 2 Kaliuntu, SDN 3 Kaliuntu, dan SDN 4 Kaliuntu. Pengambilan sampel dalam penelitian ini dilakukan dengan teknik random sampling diperoleh sampel sebanyak 58 siswa, yaitu siswa kelas III pada SDN 4 Kaliuntu sebagai kelas eksperimen yang berjumlah 31 siswa dan kelas III pada SDN 1 Kaliuntu sebagai kelas kontrol yang berjumlah 27 siswa.

Pengumpulan data dalam penelitian ini menggunakan tes essay untuk kemampuan berpikir kritis dan tes pilihan ganda untuk hasil belajar IPA. Uji persyaratan analisis dalam penelitian ini adalah: (1) uji normalitas sebaran data, (2) uji homogenitas varians, dan (3) uji korelasi antar variabel terikat. Analisis data yang digunakan adalah analisis MANOVA.

\section{HASIL DAN PEMBAHASAN}

\begin{tabular}{|c|c|c|c|c|}
\hline \multirow{2}{*}{ Statistik } & \multicolumn{2}{|c|}{ A1 } & \multicolumn{2}{|c|}{$\mathrm{A} 2$} \\
\hline & Y1 & Y2 & Y1 & Y2 \\
\hline $\mathrm{N}$ & 31 & 31 & 27 & 27 \\
\hline Rata-rata & 76,32 & 82,32 & 62,44 & 63,41 \\
\hline Median & 77 & 88 & 56 & 64 \\
\hline Varians & 230,226 & 353,892 & 294,718 & 611,328 \\
\hline Std. Deviasi & 15,173 & 18,812 & 17,167 & 24,725 \\
\hline $\begin{array}{l}\text { Nilai } \\
\text { Minimum }\end{array}$ & 33 & 36 & 35 & 16 \\
\hline $\begin{array}{l}\text { Nilai } \\
\text { Maximum }\end{array}$ & 92 & 100 & 87 & 100 \\
\hline Rentangan & 59 & 64 & 52 & 84 \\
\hline Total & 2366 & 2552 & 1686 & 1712 \\
\hline \multicolumn{5}{|c|}{$\begin{array}{ll}\text { Keterangan: } \\
\text { A1 } & =\text { Kelas eksperimen } \\
\text { A2 } & =\text { Kelas kontrol } \\
\text { Y1 } & =\text { Kemampuan Berpikir Kritis } \\
\text { Y2 } & =\text { Hasil Belajar IPA }\end{array}$} \\
\hline
\end{tabular}

rata skor kemampuan berpikir kritis siswa yang mengikuti pembelajaran dengan pendekatan saintifik berbasis problem based learning berbantuan media audio visual adalah 76,32 berada pada interval $\mathrm{X}>75$. Berdasarkan pada hasil perhitungan kategori, dapat disimpulkan bahwa kemampuan berpikir kritis siswa yang mengikuti pembelajaran dengan pendekatan saintifik berbasis problem based learning berbantuan media audio visual berkategori "Sangat Tinggi". 
Rata-rata skor hasil belajar IPA siswa yang mengikuti pembelajaran dengan pendekatan saintifik berbasis problem based learning berbantuan media audio visual adalah 82,32 berada pada interval $X>75$ Berdasarkan pada hasil perhitungan kategori, dapat disimpulkan bahwa hasil belajar IPA siswa yang mengikuti pembelajaran dengan pendekatan saintifik berbasis problem based learning berbantuan media audio visual berkategori "Sangat Tinggi".

Rata-rata skor kemampuan berpikir kritis siswa yang mengikuti pembelajaran dengan pendekatan saintifik berbasis konvensional adalah 62,44 berada pada interval $58<\mathrm{X} \leq 75$. Berdasarkan pada hasil perhitungan kategori, dapat disimpulkan bahwa kemampuan berpikir kritis siswa yang mengikuti pembelajaran dengan pendekatan saintifik berbasis konvensional berkategori "Tinggi".

Rata-rata data hasil belajar IPA siswa yang mengikuti pembelajaran dengan pendekatan saintifik berbasis konvensional adalah 63,41 berada pada interval $58<\mathrm{X} \leq 75$. Berdasarkan pada hasil perhitungan kategori, dapat disimpulkan bahwa hasil belajar IPA siswa yang mengikuti pembelajaran dengan pendekatan saintifik berbasis konvensional berkategori "Tinggi".

Uji Prasyarat analisisis meliputi uji normalitas sebaran data, uji homogenitas varians dan uji korelasi antar variabel terikat. Uji normalitas sebaran data dilakukan dengan uji Chi Kuadrat. Berdasarkan hasil analisis terlihat nilai $\mathrm{x}^{2}$ hitung dari semua kelompok data diperoleh $\mathrm{x}_{\text {hitung }}^{2}<\mathrm{x}_{\text {tabel }}^{2}$ maka sebaran data berdistribusi normal.

Uji homogenitas varians dilakukan dengan menggunakan Uji Levene's Berdasarkan hasil analisis terlihat nilai sig. Kemampuan Berpikir Kritis adalah 0,105 dan Hasil Belajar IPA adalah 0,61, karena nilai sig.> 0,05 maka data penelitian tersebut homogen.

Uji korelasi dilakukan menggunakan korelasi Product Moment. Berdasarkan hasil analisis menunjukkan bahwa $r_{x y}$ bernilai 0,499 memiliki nilai signifikan sebesar $<0,001$. Dengan demikian data penelitian tersebut menunjukkan bahwa berkorelasi agak rendah. Karena nilai $r_{x y}$ $<0,8$ maka tidak terjadi kolinearitas, sehingga analisis MANOVA dapat dilanjutkan.

Pengujian hipotesis pertama menggunakan analisis varian satu jalur (ANAVA A) melalui statistik varians ( $F$ antar) diperoleh nilai $F_{\text {hitung }}=10,683$ dan sig $=0,002$. Ini berarti sig. $<0,05$. Jadi dapat ditarik kesimpulan bahwa pengaruh pendekatan saintifik berbasis problem based learning berbantuan media audio visual terhadap kemampuan berpikir kritis pada siswa kelas III di sekolah dasar.

Implementasi pembelajaran saintifik berbasis problem based learning (PBL) berbantuan media audio visual lebih difokuskan pada keterampilan dalam menerapkan pengetahuan, memecahkan masalah, berlatih berpikir tingkat tinggi, dan mengarahkan belajar sendiri berdasarkan permasalahan yang ditayangkan pada audio visual sehingga dapat memaksimalkan kemampuan berpikir kritis siswa, sedangkan pada pembelajaran dengan menggunakan saintifik berbasis konvensional, siswa cendrung menjadi objek dalam pembelajaran dan kurang memaksimalkan kemampuan berpikir kritis siswa.

Hasil penelitian ini sejalan dengan penelitian yang dilakukan oleh Vera (2018), bahwa penggunaan model PBL berbantuan audio visual dapat meningkatkan keterampilan berfikir kritis siswa. Kemudian Bakhri (2017) menyatakan bahwa pembelajaran berbasis masalah merupakan suatu strategi pembelajaran yang mendorong siswa untuk mengembangkan kemampuan berpikir kritis dan dapat menyelesaikan masalah yang dapat digunakan mereka sepanjang hidupnya.

Perbedaan cara mengimplementasi kan pendekatan pembelajaran saintifik berbasis problem based learning berbantuan media audio visual dan pendekatan pembelajaran saintifik berbasis konvensional tentunya memberikan dampak yang berbeda terhadap kemampuan berpikir kritis siswa. Kemampuan berpikir kritis siswa yang dibelajarkan dengan pembelajaran saintifik 
berbasis problem based learning berbantuan media audio visual lebih melatih siswa untuk memecahkan masalah berdasarkan permasalahan yang dihadirkan pada tayangan audio visual. Siswa ditekankan untuk bekerjasama untuk berdiskusi dan mengkomunikasikan ide kepada teman sekelompoknya dan mengkolaborasikan secara kelompok sehingga diperoleh solusi yang baik bagi permasalahan yang dihadapi oleh siswa.

Hal tersebut dapat dilihat dari proses pembelajarannya, pada kelas eksperimen mula-mula siswa mengamati audio visual kemudian diberikan LKK yang dimaksudkan untuk merangsang berpikir kritis siswa tentang permasalahan yang dihadirkan. Kemudian secara berkelompok siswa berdiskusi, mengumpulkan informasi dan mencari solusi serta mengkomunikasikan di depan kelas.

Berbeda dengan pembelajaran pada kelas kontrol tanpa model problem based learning berbantuan audio visual, siswa diberikan permasalahan berdasarkan buku siswa, kemudian berdasarkan permasalahan yang ada dibentuk kelompok. Kemudian memperesentasikan hasil diskusi yang diperoleh.

Pengujian hipotesis kedua menggunakan analisis varian satu jalur (ANAVA A) melalui statistik varians ( $\mathrm{F}$ antar) diperoleh nilai $\mathrm{F}_{\text {hitung }}=10.906$ dan sig. $=0,002$. Ini berarti sig. $<0,05$. Jadi terdapat pengaruh pendekatan saintifik berbasis problem based learning berbantuan media audio visual terhadap hasil belajar IPA pada siswa kelas III di sekolah dasar

Implementasi pembelajaran saintifik berbasis problem based learning berbantuan media audio visual lebih difokuskan pada keterampilan dalam menerapkan pengetahuan, memecahkan masalah, berlatih berpikir tingkat tinggi, dan mengarahkan belajar sendiri berdasarkan permasalahan yang ditayangkan pada audio visual sehingga dapat memaksimalkan hasil belajar IPA, sedangkan pada pembelajaran dengan menggunakan saintifik berbasis konvensional, siswa cendrung menjadi objek dalam pembelajaran dan kurang memaksimalkan hasil belajar IPA siswa.
Hasil penelitian ini sejalan dengan penelitian yang dilakukan oleh Paramartha (2016) terdapat perbedaan yang signifikan penguasaan kompetensi pengetahuan IPA kelompok siswa yang dibelajarkan dengan model Problem Based Learning berbantuan media audio visual dan kelompok siswa yang dibelajarkan secara konvensional pada siswa kelas IV. Kemudian Virginia (2016) terdapat perbedaan tingkat efektifitas antara model problem based learning berbantu media audio visual dengan model pembelajaran think pair share berbantu media visual terhadap hasil belajar IPA siswa kelas 5 SDN 1 Gadu Kecamatan Sambong Kabupaten Blora Semester 2 Tahun 2014/2015.

Perbedaan cara mengimplementasi kan pendekatan pembelajaran saintifik berbasis problem based learning berbantuan media audio visual dan pendekatan pembelajaran saintifik berbasis konvensional tentunya memberikan dampak yang berbeda terhadap hasil belajar IPA siswa. Hasil belajar IPA siswa yang dibelajarkan dengan pembelajaran saintifik berbasis problem based learning berbantuan media audio visual memproleh hasil lebih baik dibandingkan dengan hasil belajar IPA siswa yang dibelajarkan dengan pendekatan pembelajaran saintifik berbasis konvensional. Hal ini dikarenakan pada kelas eksperimen siswa lebih terlatih dalam berpikir kritis dan pemecahan masalah, sedangkan pada kelas control hanya mengikuti apa yang terdapat pada buku siswa saja. Sehingga dapat dikatakan pendekatan saintifik berbasis problem based learning berbantuan media audio visual berpengaruh terhadap hasil belajar IPA pada siswa kelas III di sekolah dasar

Uji hipotesis ketiga dilakukan dengan uji Wilk Lambda $\left(\Lambda^{*}\right)$ melalui MANOVA menunjukkan bahwa nilai nilai Wilk Lambda $\left(\Lambda^{*}\right)=0,043$ dengan signifikansi $<0,001$, ini berarti nilai sig $<0,05$. Jadi, hipotesis nol $\left(\mathrm{H}_{0}\right)$ ditolak dan hipotesis alternatif $\left(\mathrm{H}_{1}\right)$ diterima. Jadi terdapat pengaruh pendekatan saintifik berbasis problem based learning berbantuan media audio visual terhadap kemampuan berpikir 
kritis dan hasil belajar IPA secara simultan pada siswa kelas III di sekolah dasar.

Perbedaan cara mengimplementasi kan pendekatan pembelajaran saintifik berbasis problem based learning berbantuan media audio visual dan pendekatan pembelajaran saintifik berbasis konvensional tentunya memberikan dampak yang berbeda terhadap kemampuan berpikir kritis dan hasil belajar IPA secara simultan siswa. kemampuan berpikir kritis dan hasil belajar IPA secara simultan siswa yang dibelajarkan dengan pembelajaran saintifik berbasis problem based learning berbantuan media audio visual memproleh hasil lebih baik dibandingkan dengan hasil belajar IPA siswa yang dibelajarkan dengan pendekatan pembelajaran saintifik berbasis konvensional. Sehingga dapat dikatakan pendekatan saintifik berbasis problem based learning berbantuan media audio visual berpengaruh terhadap kemampuan berpikir kritis dan hasil belajar IPA secara simultan pada siswa kelas III di sekolah dasar.

\section{PENUTUP}

Berdasarkan uji hipotesis dan pembahasan dapat ditarik kesimpulan sebagai berikut: 1). terdapat pengaruh pendekatan saintifik berbasis problem based learning berbantuan media audio visual terhadap kemampuan berpikir kritis pada siswa kelas III di sekolah dasar; 2) Terdapat pengaruh pendekatan saintifik berbasis problem based learning berbantuan media audio visual terhadap hasil belajar IPA pada siswa kelas III di sekolah dasar; 3) Terdapat pengaruh pendekatan saintifik berbasis problem based learning berbantuan media audio visual terhadap kemampuan berpikir kritis dan hasil belajar IPA secara simultan pada siswa kelas III di sekolah dasar.

Hasil penelitian ini disarankan kepada para guru yang diharapkan mampu untuk melakukan inovasi dalam mengembangkan model pembelajaran yang inovatif, dapat mendayagunakan segala sesuatu fasilitas sekolah sebagai alat bantu mengajar sehingga pembelajaran dapat terlaksana dengan sangat baik, dan lebih kreatif dalam merancang dan mempersiapkan media pembelajaran yang inovatif dan menyenangkan bagi siswa.

\section{DAFTAR RUJUKAN}

Agustiana, I.G.A.T dan Tika, I.N. 2017. Konsep Dasar IPA. Yogyakarta: Ombak

Asri, B.W, Nurhalim, K dan Suhandini, P. 2019. " The Implementation of Talking Stick Model Assisted by Audio-Visual Media Toward Positive Character and Learning Outcome", Journal of Primary Education. 8 (2): 225-231

Aunurrahman. 2012. Belajar dan Pembelajaran. Bandung: Alfabeta

Bakhri, S dan Supriadi. 2017. "Peran Problem-Based Learning (PBL) dalam Upaya Peningkatan Higher Order Thinking Skills (HOTS) Siswa pada Pembelajaran Matematika" Seminar Matematika dan Pendidikan Matematika UNY : PM-717-PM-722

Dantes, N. 2014. Landasan Pendidikan; Tinjau Dari Dimensi Makropedagogis. Yogyakarta: Graha IImu.

Garbier, E, Bailly G dan Bosse, M.L. 2018. "Audio-visual Synchronization in Reading While Listening to Texts: Effects on Visual Behavior and Verbal Learning". Computer Speech and Language, Elsevier,47, p.p 7992.

Hidayati, A.U dan Ratnawati, $H$. 2016."Effectiveness Problem Based Learning and Scientific Approach to Improve Higher Order Thinking Skills",Implementation and Education of Mathematic and Science, ME 55-ME 60

Masyhud, M. S. 2014. Metode Penelitian Pendidikan. Jember: Lembaga Pengembangan Manajemen dan Profesi Kependidikan (LPMPK)

Paramartha, I,M,D, Suniasih, N.W dan Negara, I.G.A.O. 2016. "Pengaruh Model PBL Berbantuan Media Audio Visual Terhadap Penguasaan Kompetensi Pengetahuan IPA", eJournal PGSD Universitas Pendidikan Ganesha,1(4),1-10 
Pebriana, R dan Disman. 2017. "Effect Of Problem Based Learning To Critical Thingking Skills Elementary School Students In Social Studies", Journal of Elementary Education, 1(1):109118

Peraturan Menteri Pendidikan Dan Kebudayaan Republik Indonesia No. 21 Tahun 2016 Standar Isi Pendidikan Dasar dan Menengah. Jakarta: Kementrian Pendidikan Nasional RI

Undang- Undang Republik Indonesia Nomor 20 Tahun 2003 Tentang Sistem Pendidikan Nasional. 2003. Jakarta: Kementrian Pendidikan Nasional RI.

Vera, K dan Wardani, K.W. 2018. "Peningkatan Keterampilan Berfikir Kritis Melalui Model Problem Based Learning Berbantuan Audio Visual pada Siswa Kelas IV SD",Jurnal Riset Teknologi dan Inovasi Pendidikan,2(1),33-45

Virginia, A dan Wasitohadi. 2016. "Efektifitas Model Problem Based Learning Berbantuan Media Audio Visual Ditinjau dari Hasil Belajar IPA Siswa Kelas 5 SDN 1 Gadu Sambong-Blora Semester 2 Tahun 2014/2015", Jurnal Pendidikan dan Kebudayaan,2(6), 100-118

Wijaya, E. Y. 2016. "Tranformasi Pendidikan Abad 21 sebagai Tuntutan Pengembangan Sumber Daya Manusia di Era Global", Prosiding Seminar Nasional Pendidikan Matematika 2016,

(1),263-278

Zejnilagić-Hajrić, M. ${ }^{*}$, Šabeta, A., dan Nuić, I. 2015. "The effects of problembased learning on students' achievements in primary school chemistry", Bulletin of the Chemists and Technologists of Bosnia and Herzegovina, 44,17-22 